\title{
STABILIZATION OF HIGHWAY EXPANSIVE SOILS WITH HIGH LOSS ON IGNITION CONTENT KILN DUST
}

\author{
A. B. Salahudeen ${ }^{1, *}$ and I. Akiije ${ }^{2}$ \\ 1Samaru College of Agriculture, Division of Agricultural Colleges, Ahmadu Bello Univ., Zaria, NigERIA \\ ${ }^{2}$ DEPARTMENT OF CIVIL AND ENVIRONMENTAL ENGINEERING, UNIVERSITY OF LAGOS, LAGOS, NIGERIA
}

E-mail addresses: ${ }^{1}$ muazbj@gmail.com, ${ }^{2}$ akiijeia@yahoo.com.

\begin{abstract}
This study was carried out to evaluate the effect of high loss on ignition content cement kiln dust on the stabilization of highway expansive soils. Laboratory tests were performed on the natural and stabilized soil samples in accordance with BS 1377 (1990) and BS 1924 (1990), respectively. The preliminary investigation carried out on the expansive soil (also known as black cotton soil) found in Deba, Gombe State, Nigeria shows that it falls under Silt-Clay material of Group A-7-6 (16) using AASHTO classification and inorganic clay material CL according to Unified Soil Classification System (USCS). The maximum dry density (MDD) for British Standard Light (BSL) and British Standard Heavy (BSH) compactive efforts increased to peak values of 1.66 and $1.91 \mathrm{Mg} / \mathrm{m}^{3}$ at $6 \%$ and $4 \%$ cement kiln dust (CKD) contents respectively. The MDD for West African Standard (WAS) compactive effort increased with higher CKD content. The Optimum Moisture Content (OMC) for BSL and BSH compactive efforts increased up to 6\% CKD content then decreased with higher CKD content. For the WAS compactive effort, the OMC generally decreased with higher CKD content. The unsoaked California bearing ratio (CBR) values of 3, 5 and 7\% for the natural soil compacted with BSL, WAS and BSH compactive efforts, respectively, increased to 7, 10 and 19\% at 10\% CKD content. The 24 hour soaked CBR values of the natural soil of 3\% for BSL, 3\% for WAS and 5\% for BSH compactive energies, respectively increased to their peak values of 5\%,6\% and 8\% respectively at $10 \%$ CKD content
\end{abstract}

Keywords: Modification, Cement Kiln Dust, Black Cotton Soil, California bearing ratio

\section{INTRODUCTION}

Geotechnically, soil improvement could either be by modification or stabilization, or both. Soil modification is the addition of a modifier (cement, lime, cement kiln dist, etc) to a problem soil to improve its index properties for better usefulness, while soil stabilization is the treatment of problem soils to improve their index properties and strength characteristics such that they permanently become suitable for construction and meet engineering design standards.

In all engineering design, the principal aim is to design against failure [1]. The need to reduce the cost of waste disposal and the growing cost of soil stabilizers has led to intense global research towards economic utilization of wastes for engineering purposes. For this is prodigy to a safe disposal of industrial and agricultural wastes that requires urgent and cost effective solutions to the devastating effect of these materials on the environment and health hazards that they constitute.

Expansive soils are also referred to as "black cotton soil" in some parts of the world like Nigeria. They are so named because of their colour and suitability for growing cotton. Black cotton soils have colours ranging from light grey to dark grey and black [2]. Black cotton soils are confined to the semi-arid regions of tropical and temperate climatic zones and are abundant where the annual evaporation exceeds the precipitation $[3,4]$. Black cotton soils occur in continuous stretches as superficial deposits and are typical of flat terrains with poor drainage. The absence of quartz in the clay mineralogy enhances the formation of fine-grained soil material, which is impermeable and waterlogged [5].

The mineralogy of this soil is dominated by the presence of montmorillonite which is characterized by large volume change from wet to dry seasons and vice

* Corresponding author, Tel: +234-8063600851 
versa. Deposits of black cotton soil, which occupy an estimated area of $104 \times 10^{3} \mathrm{~km}^{2}$ in North-Eastern Nigeria, show a general pattern of cracks during the dry season of the year. Cracks measuring $70 \mathrm{~mm}$ wide and over $1 \mathrm{~m}$ deep have been observed and may extend up to $3 \mathrm{~m}$ deep or more in case of high deposit [6].

Cement kiln dust (CKD) or cement by-pass dust (CBPD) is the fine grained, solid highly alkaline waste removed from cement kiln exhaust gas by air pollution control devices. A typical Portland cement is manufactured by feeding materials containing appropriate proportions of lime, silica, alumina and iron into the upper end of a kiln. The mix passes through the kiln at a rate controlled by the slope of the kiln and the speed at which the kiln rotates. Burning fuel is forced into the lower end of the kiln where it produces temperatures of $1400-1650^{\circ} \mathrm{C}$, changing the raw mix to a cement clinker. During this operation a small percentage of the material in the form of dust (i.e. CKD) is collected. The physical and chemical properties of CKD can vary from plant-to-plant, depending on the raw materials used and type of collection process in the plant. However, the dust collected from the same kiln and producing the same cement type will typically have a relatively consistent composition.

The major parameters that determine CKD characteristics are the raw feed material, type of kiln operation, dust collection systems, and fuel type. Since the properties of CKD can be significantly affected by the design, operation and materials used in a cement kiln, the chemical and physical characteristics of CKD must be evaluated on an individual plant basis [7].

CKD containing high $\mathrm{CaO}$ content and low loss on ignition (LOI) performs best for most applications [8]. High LOI dusts contain a higher percentage of bound water within its chemical structure and less $\mathrm{CaO}$ is available to react. The high LOI can also interfere with the hydration process. Several processing factors influence the chemical and physical properties of CKD. Because plant operations differ considerably with respect to raw feed, type of operation, dust collection facility, and type of fuel used, CKD from each plant can vary markedly in chemical, mineralogical and physical composition. Therefore it is important to thoroughly test CKD upon high or low loss of ignition content for any proposed application for soil modifications or stabilization prior to use [8].

Bhatty and Todres [9], reviewed some existing literatures and summarized them as follows:
- CKD with high free lime $(\approx 15 \%)$ and low alkalies (< $4 \%$ water soluble $\mathrm{K}_{2} \mathrm{O}=\mathrm{Na}_{2} \mathrm{O}$ or $<3 \% \mathrm{Na}_{2} \mathrm{O}$ equivalent) resulted in improved compressive strengths for clay soils.

- CKDs with low free lime $(<8 \%)$ and high alkali CKD ( $>7 \%$ water soluble $\mathrm{K}_{2} \mathrm{O}=\mathrm{Na}_{2} \mathrm{O}$ or $>3 \% \mathrm{Na}_{2} \mathrm{O}$ equivalent) adversely affected the unconfined compressive strength.

- High loss on ignition (LOI) indicates that the CKD is high in slow-reacting calcium carbonate and low in reactive free lime. A high LOI was not defined numerically, however a CKD with a LOI of $28 \%$ was described as high.

- Higher concentrations of alkalies in CKDs can counter stabilization reactions because of ionic interference.

- CKD with low LOI $(<9 \%)$ and moderate alkalies $\left(>3 \% \mathrm{Na}_{2} \mathrm{O}\right)$ reduced the PI and improved the unconfined compressive strength.

- CKDs with moderate free lime and low alkalies were shown to improve plastic indices, reduce swelling, and improve strength and durability.

\section{MATERIALS AND METHODS}

\subsection{Materials}

The disturbed black cotton soil samples used for this study were collected in March, 2012 at Deba (Latitude $10^{\circ} 13^{\prime} \mathrm{N}$ and longitude $11^{\circ} 23^{\prime} \mathrm{E}$ ), Gombe State, Nigeria. The Cement Kiln Dust (CKD) was obtained from Sokoto Cement Factory, Sokoto, the capital of Sokoto State of Nigeria directly from the factory's kiln dust collection cylinder. The characterization of the CKD by determining its chemical composition was conducted by method of Energy Dispersive X-Ray Fluorescence at the Nigerian Geological Survey Agency, BarnawaKaduna. The loss on ignition content of the CKD used in this study was characterized as high (39.28\%) considering the literature review of Bhatty and Todres [9].

Laboratory tests were performed on the natural soil samples in accordance with BS 1377 [10] and on the cement kiln dust treated black cotton soil in accordance with BS 1924 [11]. These tests include, particle size distribution, Atterberg limits, compaction characteristics and California bearing ratio tests.

\subsection{Methods}

\subsubsection{Particle Size Distribution}

The particle size analysis test was carried out in accordance with BS 1377; 1990 Part 2. Wet sieving was conducted by measuring $200 \mathrm{~g}$ of the soil sample 
and soaking it for 24hours. The sample was then washed through BS No 200sieve. The particles retained were then dried in the oven for 24 hours and a dry sieving was carried out on the dried sample, while hydrometer sedimentation test was carried out on the portion passing BS No 200sieve to obtain the particle size distribution.

\subsubsection{Atterberg limits}

The test includes the determination of the liquid limits, plastic limits and the plasticity index of the natural and CKD-stabilized soils. They were conducted in accordance with Test 3 of the BS 1377 (1990) Part 2.

\subsubsection{Compaction test}

The compaction tests were carried out on the natural soil and the stabilized soils with 0, 2, 4, 68 and $10 \%$ of CKD; using the British Standard light (BSL), West African Standard (WAS) and the British Standard heavy (BSH) energies, in accordance with the Nigerian General Specifications [12].

\subsubsection{California bearing ratio test}

The strength characteristic test performed in this study is the California bearing ratio (CBR) test. It was carried out in accordance with the Nigerian General Specification [12] which specified that specimen be cured in the dry for six days and then soaked for 24 hours before testing.

\section{RESULTS AND DISCUSSION}

\subsection{Chemical Composition of Cement Kiln Dust}

The result of the chemical composition test is shown in Table 1.

\subsection{Soil Identification}

The results of the identification test conducted on the natural soil are summarized in Table 2 .

\subsection{Particle Size Distribution}

The particle size analysis from hydrometer sedimentation test for black cotton soil - cement kiln dust mixures are shown in Figure 1. On a general note, a nominal increase in the percentage fines was observed with increasing cement kiln dust content. This was as a result of the soil particles been replaced by the finer CKD particles, hence the increased finer particles.
Table 1: Chemical Composition of Cement Kiln Dust

\begin{tabular}{cc}
\hline Oxide & Percentage of oxide in CKD \\
\hline $\mathrm{CaO}$ & 44.28 \\
$\mathrm{SiO}_{2}$ & 7.24 \\
$\mathrm{Al}_{2} \mathrm{O}_{3}$ & 1.90 \\
$\mathrm{Fe}_{2} \mathrm{O}_{3}$ & 4.47 \\
$\mathrm{MgO}$ & 0.82 \\
$\mathrm{MnO}$ & 0.11 \\
$\mathrm{In}_{2} \mathrm{O}_{3}$ & 0.66 \\
$\mathrm{BaO}$ & 0.11 \\
$\mathrm{SO}_{3}$ & 0.13 \\
$\mathrm{Lu}_{2} \mathrm{O}_{3}$ & 0.05 \\
$\mathrm{LOI}\left(1000^{\circ} \mathrm{C}\right)$ & 39.28 \\
$\mathrm{CdO}$ & 1.3 \\
$\mathrm{Re}_{2} \mathrm{O}_{7}$ & 0.21 \\
\hline
\end{tabular}

Table 2: Properties of the Natural Black Cotton Soil

\begin{tabular}{|c|c|}
\hline Property & Quantity \\
\hline $\begin{array}{l}\text { Percentage passing BS No } 200 \\
\text { sieve }\end{array}$ & 73.6 \\
\hline Natural Moisture Content, \% & 21.0 \\
\hline Liquid Limit, \% & 48.2 \\
\hline Plastic Limit, \% & 27.2 \\
\hline Plasticity Index, \% & 21.0 \\
\hline Linear Shrinkage, \% & 16.9 \\
\hline Free Swell, \% & 80.0 \\
\hline Specific Gravity & 2.33 \\
\hline AASHTO Classification & A-7-6 (16) \\
\hline USCS & CL \\
\hline NBRRI Classification & $\begin{array}{l}\text { High swell } \\
\text { potential }\end{array}$ \\
\hline \multicolumn{2}{|l|}{ Maximum Dry Density, $\mathrm{Mg} / \mathrm{m}^{3}$} \\
\hline British Standard light & 1.63 \\
\hline West African Standard & 1.72 \\
\hline British Standard heavy & 1.82 \\
\hline \multicolumn{2}{|l|}{ Optimum Moisture Content, \% } \\
\hline British Standard light & 18.0 \\
\hline West African Standard & 17.9 \\
\hline $\begin{array}{l}\text { British Standard heavy } \\
\text { California Bearing Ratio ( } 24 \mathrm{hr} \\
\text { soaking), } \%\end{array}$ & 14.6 \\
\hline British Standard light & 3 \\
\hline West African Standard & 3 \\
\hline British Standard heavy & 5 \\
\hline Colour & Greyish black \\
\hline Dominant clay mineral & Montmorillonite \\
\hline
\end{tabular}

\subsection{Effect of CKD on Atterberg Limits}

The variation of liquid limit of black cotton soil with cement kiln dust content is shown in Fig. 2. The introduction of cement kiln dust into the soil first 
caused an increase in the Atterberg limits to a peak value at $2 \%$ CKD treatment in the case of the liquid limit and 4\% CKD treatment for plastic limit and linear Shrinkage and thereafter decreased. The increase can be attributed to addition of CKD which introduced more pozzolanic substance into the specimen that required more water for hydration to be completed. The subsequence decrease can be associated with the agglomeration and flocculation of the clay particles which is as a result of exchange ions at the surface of the clay particles. The trend observed in liquid and plastic limits is in agreement with Ramzi et al. [13]. There was a general decrease in the plasticity index value from a value of $21.0 \%$ for the natural soil to a least value of $12.8 \%$ at $6 \%$ CKD treatment. [14] and [15] reported that the reduction in plasticity index with chemical treatment could be attributed to the depressed double layer thickness due to cation exchange by potassium, calcium and ferric ions. A nominal increment was observed at 8 and $10 \%$ CKD contents.

\subsection{Effect of CKD on Compaction Characteristics 3.4.1 Maximum Dry Density}

The variation of maximum dry density (MDD) of black cotton soil with cement kiln dust contents for the three compactive efforts are shown in Fig. 3.

For British Standard light (BSL) and British Standard Heavy (BSH) compactions, the MDD increased from 1.63 and $1.82 \mathrm{Mg} / \mathrm{m}^{3}$ for the natural soil to 1.66 and $1.91 \mathrm{Mg} / \mathrm{m}^{3}$ at 4 and $6 \%$ CKD contents respectively.

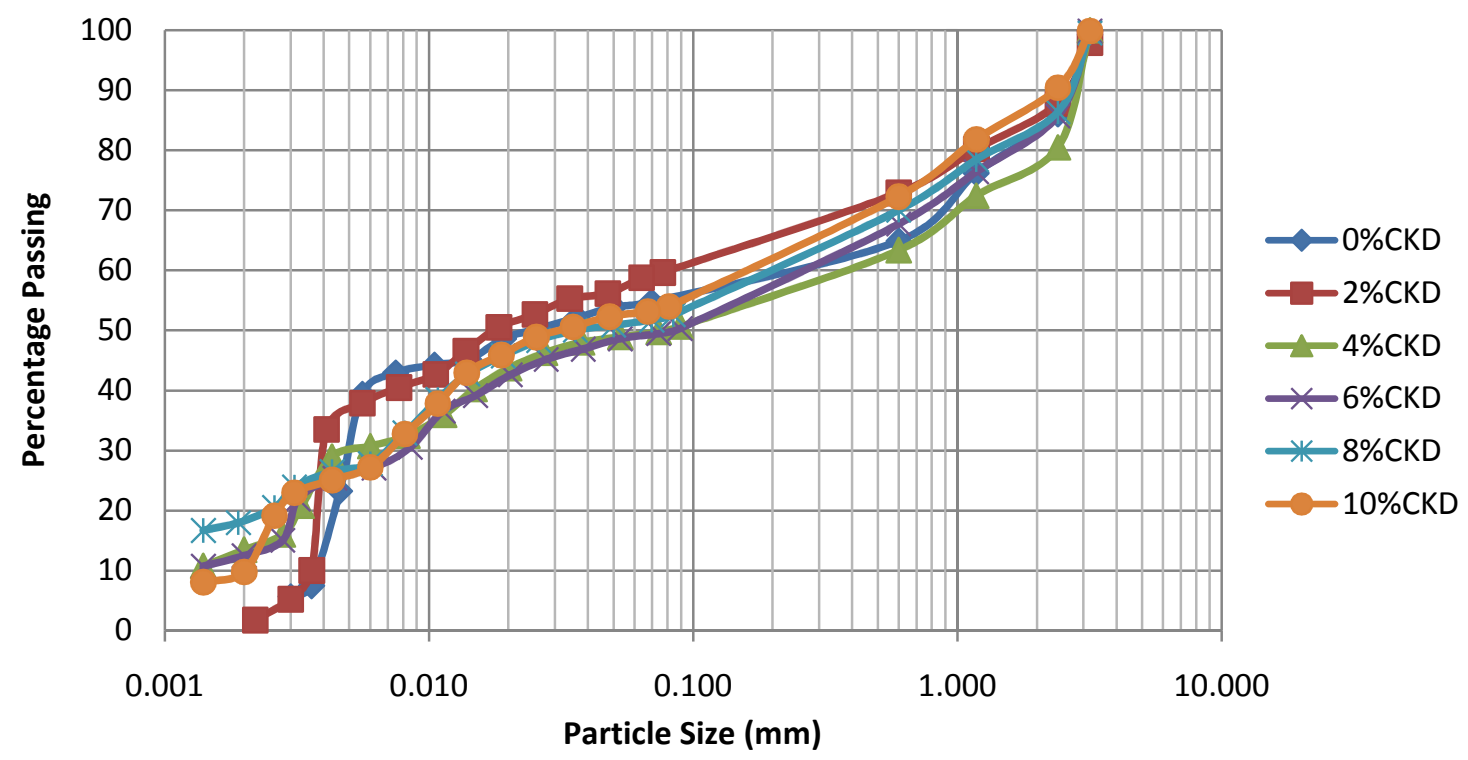

Figure 1: Particle Size Distribution curves of combined Dry and Hydrometer Sedimentation Tests of Black Cotton Soil-Cement Kiln Dust Mixtures

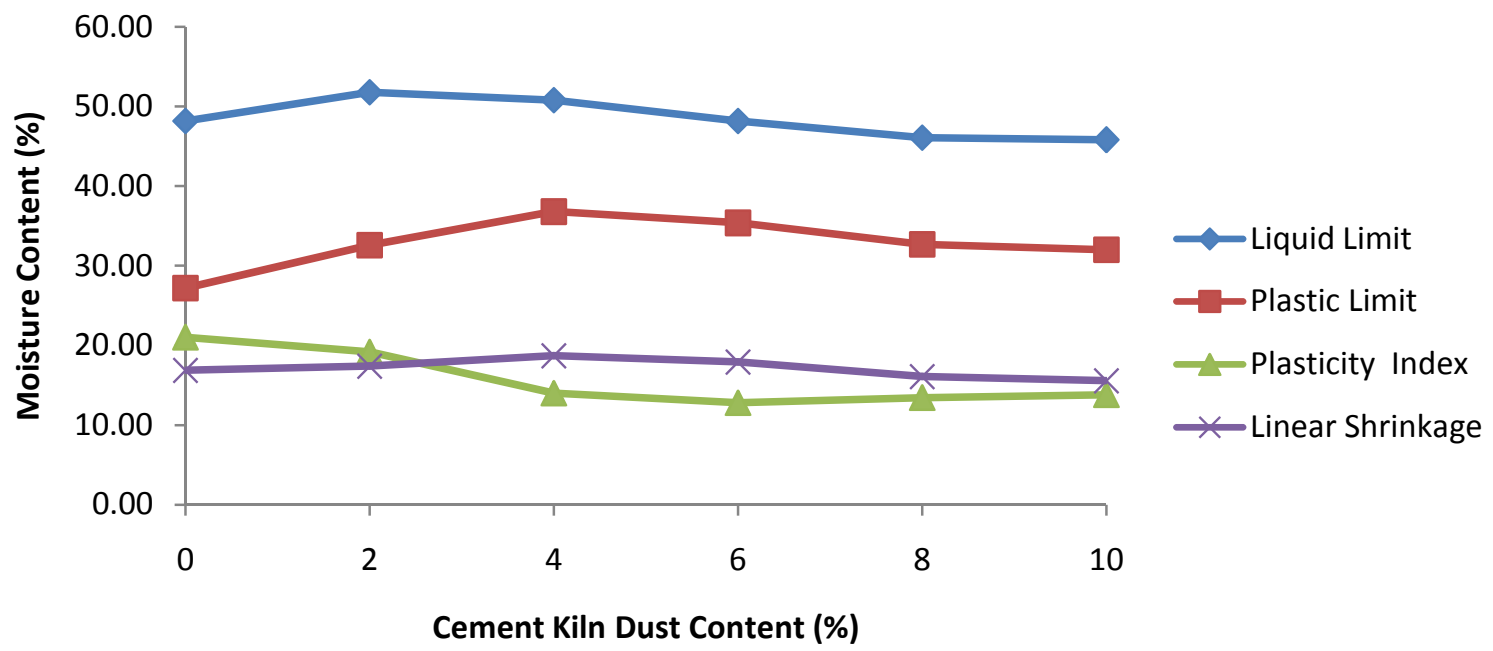

Figure 2: Variation of Atterberg Limits of Black Cotton Soil with Cement Kiln Dust Content 
This increase in dry density with addition of CKD may be due to cation exchange reactions. It could also be due to CKD occupying the void within the soil matrix and in addition, the flocculation and agglomeration of the clay particle due to exchange of ions $[1,16,17$,$] .$ The subsequent reduction in MDD may be probably due to the fact that for any soil/admixture, there is always a water content to produce maximum strength [18]. This trend is in agreement with Ola [19], Lees et al. [20] and Iorliam et al. [21]. The result of the West African Standard (WAS) compaction is in conformity with the trend of decreasing OMC with increasing MDD.

\subsubsection{Optimum Moisture Content}

The variation of optimum moisture content of black cotton soil with cement kiln dust contents for the three compactive efforts is shown in Fig.4. For BSL and BSH compactions, the OMC increased from values of $18.0 \%$ and $14.6 \%$ for the natural soil to peak values of $19.7 \%$ and $15.8 \%$ both at $6 \%$ CKD contents.

This trend is in conformity with results reported by Ola [22], Gidigasu [23] and Osinubi [18]. An explanation that was offered for this trend is that there was increasing desire for water which commensurates with the higher amount of the additives because more water was required for the dissociation of admixtures with $\mathrm{Ca}^{2+}$ and $\mathrm{OH}^{-}$ions to supply more $\mathrm{Ca}^{2+}$ for the cation exchange reaction. The subsequent decrease in OMC with increase in CKD content might be due to cation exchange reaction that caused the flocculation of clay particles.

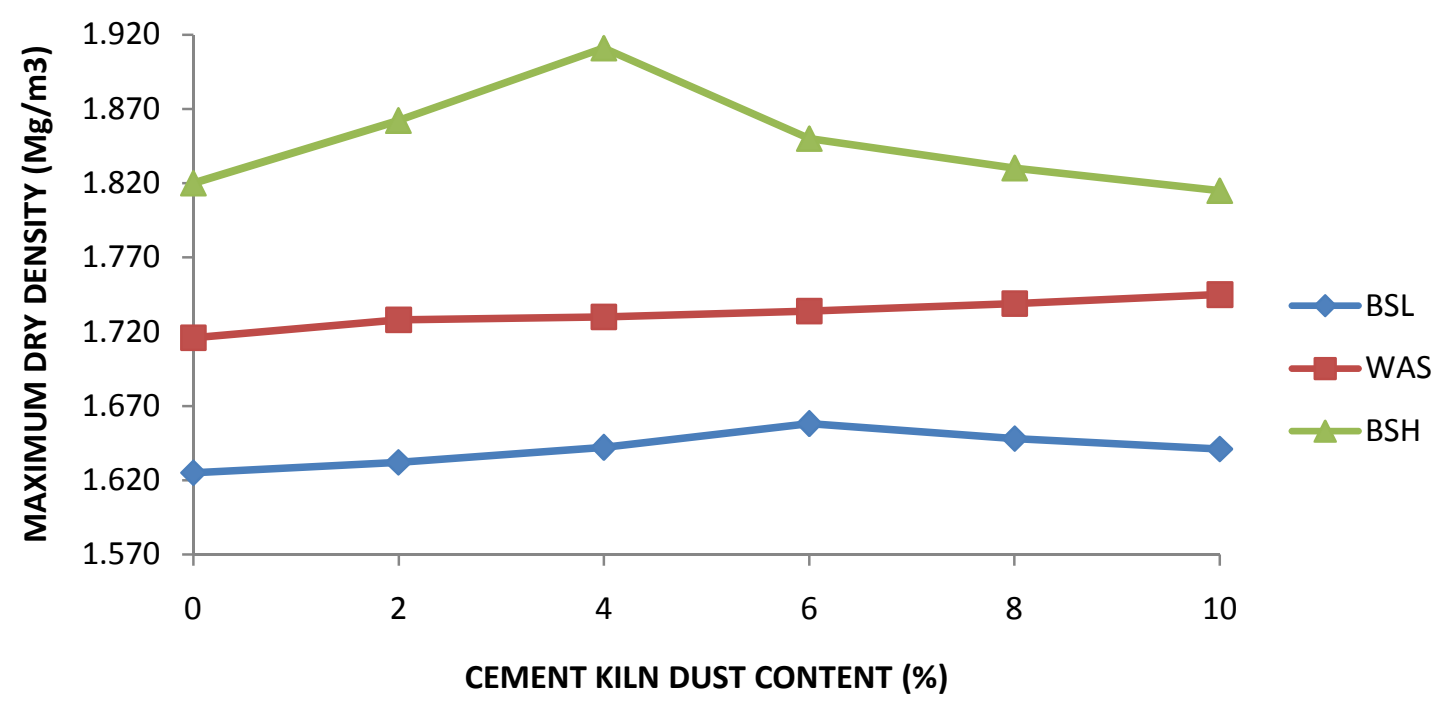

Figure 3: Variation of Maximum Dry Density of Black Cotton Soil with Cement Kiln Dust Content

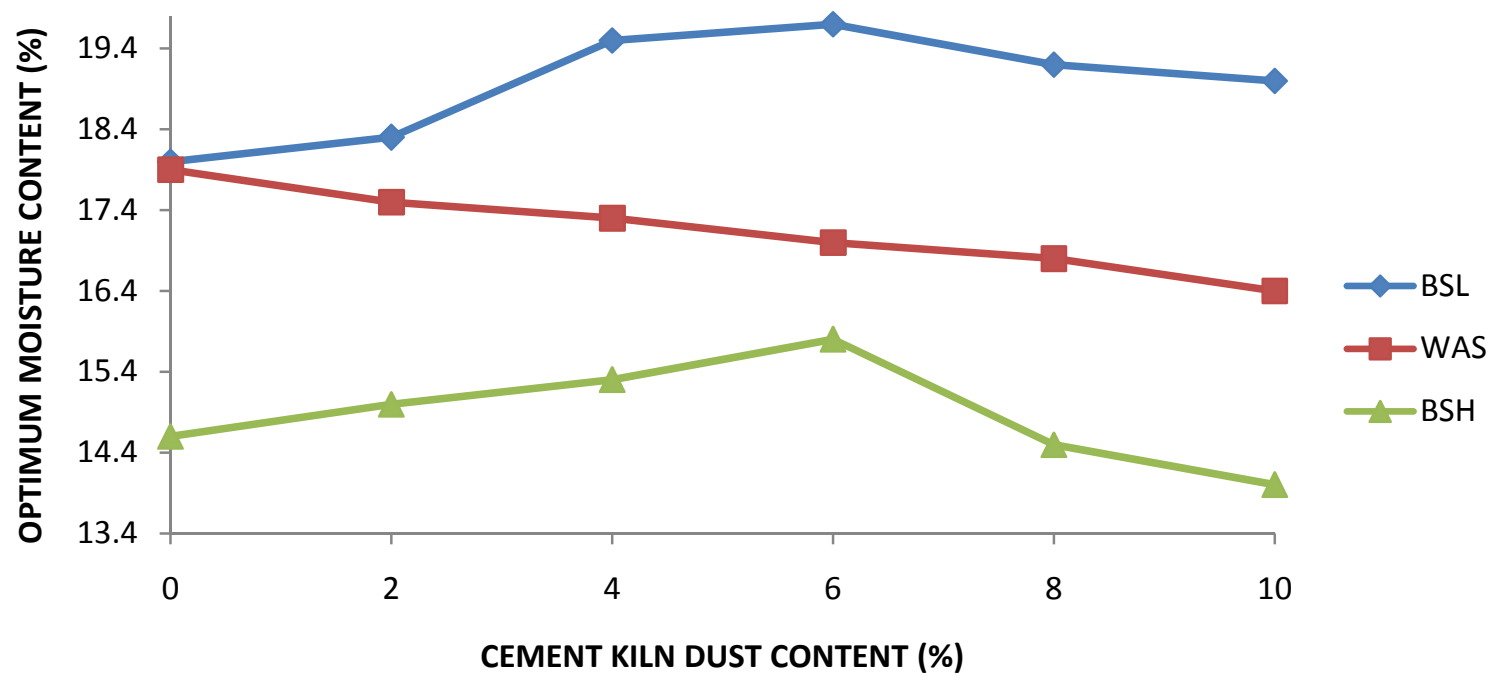

Figure 4: Variation of Optimum Moisture Content of Balck Cotton Soil with Cement Kiln Dust 


\subsection{California Bearing Ratio}

\subsubsection{Unsoaked CBR}

The variation of the unsoaked CBR values with cement kiln dust content for the three energy levels used for compaction is given in Figure 5. A general increase in CBR values with CKD content was observed. This increase could be due to the presence of adequate amounts of calcium required for the formation of calcium silicate hydrate (CSH) and calcium aluminate hydrate (CAH), which are the major compounds responsible for strength gain. The soil -CKD mixtures failed to meet the minimum CBR value of $30 \%$ specified by (BS 1990) for materials suitable for use as base course material when determined at MDD and OMC.

The highest unsoaked CBR value of $18.82 \%$ was observed at $10 \%$ CKD content using the $\mathrm{BSH}$ compactive effort. This is close to the findings of Gidigasu and Dogbey (1980) [24], which stated that minimum CBR value of $20-30 \%$ is required for subbases when compacted at OMC.

\subsubsection{Soaked CBR}

The variations of soaked CBR (24 hours soaking) of natural and CKD-stabilized soil using BSL, WAS and BSH compactive efforts are shown in Figure 6. It was observed that the CBR values, both unsoaked and soaked, increased with higher CKD contents and higher compactive effort.

\section{CONCLUSION}

From the results of the study conducted, the following conclusions can be drawn.

* The black cotton soil is classified as A-7-6 (16) using the AASHTO classification system and CL using the USCS. This makes it geotechnically a problem soil.

* A high lost on ignition (LOI) content cement kiln dust (CKD) has no significant effect on the particle sizes of black cotton soil.

* The effect of high LOI content CKD on the Atterberg limits is most significant (for soil modification) at $10 \%$ or more.

* Generally, the chemical, mineralogical and physical composition of CKD should be thoroughly evaluated on an individual plant basis because several processing factors influence them.

* Cement kiln dust with high Loss on Ignition and alkali contents should be avoided in use for expansive soil modifications due to its low CBR values.

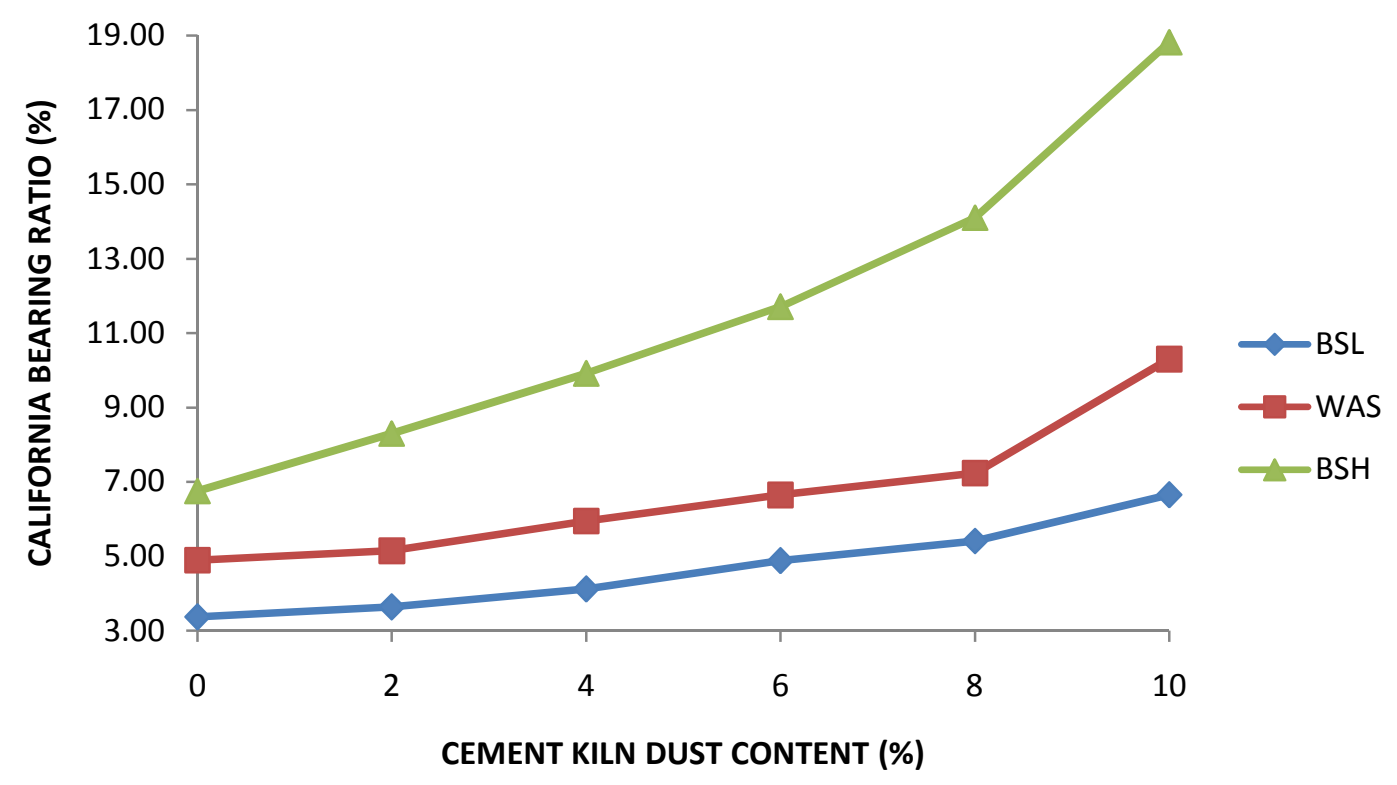

Figure 5: Variation of Unsoaked California Bearing Ratio of Black Cotton Soil with Cement Kiln Dust Content 


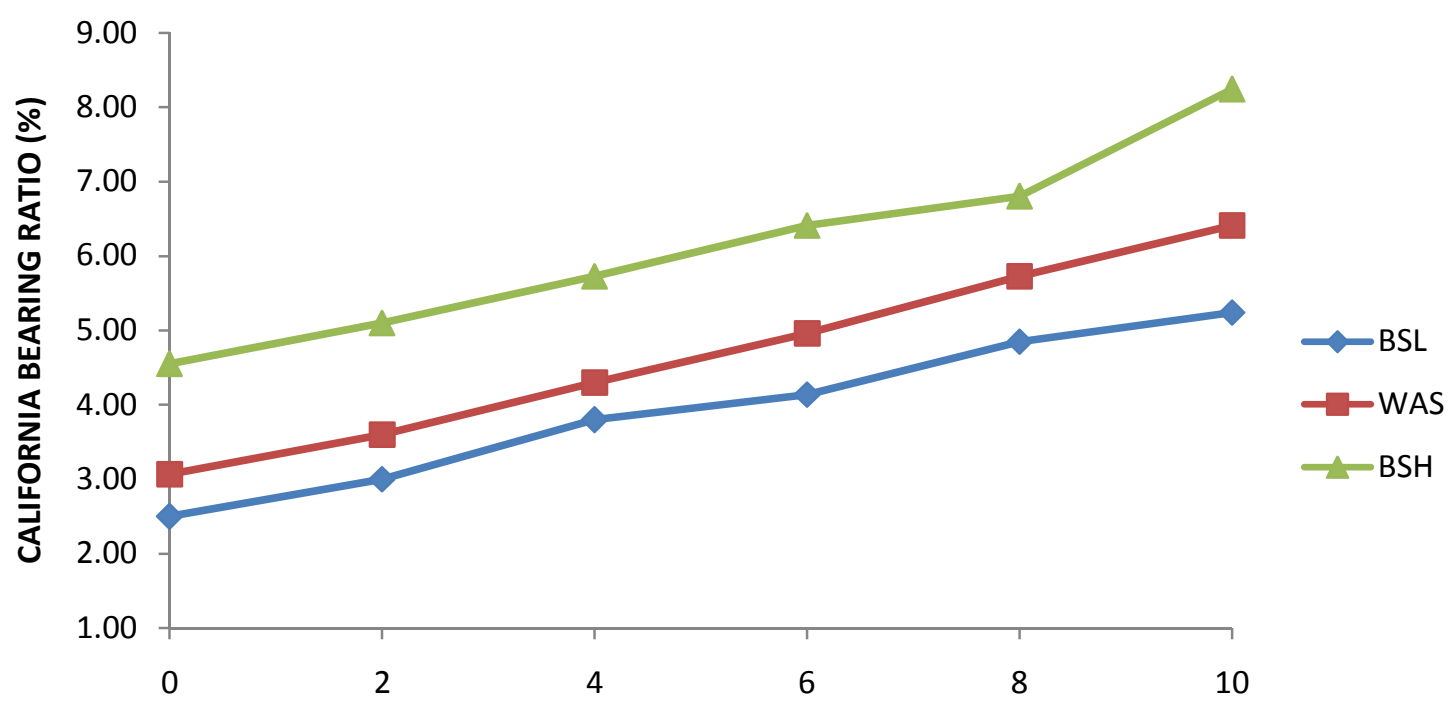

CEMENT KILN DUST CONTENT (\%)

Figure 6: Variation of Soaked California Bearing Ratio of Black Cotton Soil with Cement Kiln Dust Content

\section{REFERENCES}

[1] Salahudeen, A.B., Akiije, I. and Usman, G.M. (2013). Effect of sectional modulus on universal and hollow steel columns subjected to flexure. IJERT. Vol. 2 issue 9, pp 1848-1864.

[2] Oriola, F., and Moses, G. (2011). “Compacted black cotton soil treated with cement kiln dust as hydraulic barrier material'. AJSIR, 2011,Vol.2,No.4. pp.521-530.

[3] Chen, F. H. (1988). Foundation on Expansive Soils. Elsevier Scientific Publication Company, Amsterdam.

[4] Warren, K. W. and Kirby, T. M. (2004). "Expansive clay soil: A widespread and costly geohazard." Geostrata, Geo-Institute of the American Society Civil Engineers, Jan pp. 24-28.

[5] Balogun, L. A. (1991). "Effect of sand and salt additives on some geotechnical properties of lime stabilized black cotton soil." The Nigeria Engineer, Vol 26, No 2, pp. 15-24.

[6] Adeniji, F. A. (1991). "Recharge function of vertisolic Vadose zone in sub-sahelian Chad Basin." Proceedings $1^{\text {st }}$ International Conference on Arid Zone Hydrology and Water Resource, Maiduguri, pp. 331-348.

[7] Rahman M.K., Rehman S. and Al-Amoudi S.B. (2011). "Literature review on cement kiln dust usage in soil and waste stabilization and experimental investigation" IJRRAS 7 pp. 77-78.
[8] Wayne S.A. and Donald H.T. (2008). "Beneficial Uses OfCement Kiln Dust”. IEEE/PCA. P.1-16.

[9] Bhatty, J.I. and Todres, H.A. (1996). Use of Cement Kiln Dust in Stabilizing Clay Soils.Portland Cement Association. Skokie, Illinois. p. 2

[10] B.S. 1377 (1990). Methods of Testing Soil for Civil Engineering Purposes. British Standards Institute, London.

[11] B.S. 1924 (1990). Methods of Tests for Stabilized Soils. British Standards Institute, London.

[12] Nigerian General Specifications (1997). Roads and Bridges. Federal Ministry of Works, Abuja, Nigeria.

[13] Ramzi, T., Amer, A., Ali, A. and Hilia A. (2001). "Use Of Cement Kiln Dust In Soil Stabilization”. EJUQ. Vol.14 pp.61-76.

[14] Venkaramuthyalu, P., Ramu, K., and Prasada, R.G.V.R. (2012). "Study on performance of chemically stabilized expansive soil'. IJAET, Vol. 2, Issue 1, pp 139-148.

[15] Suhail, A.A.A., Khawla, A.K.A. and Ibrahaim, M.A.A. (2008). "Strength Durability And Hydraulic Properties Of Clayey Soil Stabilized With Lime And Industrial Waste Lime". Al-Rafidain Engineering. Vol. 16. No. 1. Pp.102-116.

[16] Osinubi, K. J. (2000). "Laboratory trial of soil stabilization of Nigerian black cotton soils" Nigerian Society of Engineers Technical Transactions, Vol. 35, No 4 pp $13-21$.

[17] Oriola, F., and Moses, G. (2010). "Groundnut Shell Ash Stabilization of Black Cotton Soil". Electron 
Journal of Geotechnical Engineering, Vol. 15, pp. 415-428.

[18] Osinubi, K. J. (1999). "Evaluation of admixture stabilization of Nigerian black cotton soil." Nigerian Society of Engineers Technical Transactions, Vol. 34, No 3, pp 88-96

[19] Ola, S. A. (1991). "Laboratory testing and geotechnical characterization of black cotton soil and expansive shales in Nigeria", Proceedings 9th Regional Conference for Africa on Soil Mechanics and Foundation Engineering, Balkema, Rotterdam, 991 - 995.

[20] Lees, G., Addelkader, M. O. and Hamdani, S. K. (1982). "Sodium chloride as additive in lime- soil stabilization" Journal Institute of Highway Engineers., 29, Vo; No(11), pp.8-16.
[21] Iorliam, A.Y., Agbede,I.O. and Joel, M. (2012). “Effect of Cement Kiln Dust On Some Geotechnical Properties of Black Cotton Soil". EJGE. Vol. 17. pp.967-976.

[22] Ola, S. A. (1978) "The geology and geotechnical properties of the black cotton soils of North Eastern Nigeria." Engineering Geology, Vol. 12, pp. 375-391.

[23] Gidigasu, M.D. (1976). Laterite Soil Engineer-ing: Pedogenesis andEngineering

Principles. Elsevier, Amsterdam, the Netherlands.

[24] Gidigasu, M.D. and Dogbey, J.L.K. (1980)."Geotechnical characterization of laterized decomposed rocks for pavement construction in dry sub-humid environment". 6th South East Asian Conf. on Soil Engineering, Taipei, 1, 493-506. 